\title{
Analysis of physicochemical parameters of hospitals wastewater: a case study in Faisalabad, Pakistan
}

\author{
Hamza Rehman, Nida Ahmad Khan*, Hasooba Hira and Asma Bibi
}

Department of Zoology, Wildlife \& Fisheries, Faculty of Sciences, University of Agriculture Faisalabad-Pakistan *Corresponding author's email: nida.ahmad96@yahoo.com

Citation

Hamza Rehman, Nida Ahmad Khan, Hasooba Hira and Asma Bibi. Analysis of physicochemical parameters of hospitals wastewater: a case study in Faisalabad, Pakistan. Pure and Applied Biology. Vol. 9, Issue 1, pp1191-1198. http://dx.doi.org/10.19045/bspab.2020.90125

Received: 12/11/2019 Revised: 26/01/2020 Accepted: 30/01/2020

Online First: 07/02/2020

\section{Abstract}

Water is the supreme essential thing that has direct effects on the life of any living organism. Water contamination is one of the alarming problem in our society and that contaminated water also includes wastewater of hospitals and laboratories. Blood and urine both are major agents that are present in the sewage of hospitals. The main objective of this study was to analyze the physicochemical parameters of sewage water of hospitals in Faisalabad city. Sewage water samples were collected from 13 different hospitals of the Faisalabad. Different physicochemical parameters like Total dissolved solids, Total hardness, Calcium, Magnesium, Bicarbonate and Chloride were analyzed in sewage water and their values were compared with the standard values given by the World Health Organization. Total dissolved solids of Faisal hospital were maximum $2710 \mathrm{mg} / \mathrm{l}$ whereas, the topmost total hardness $580 \mathrm{mg} / \mathrm{l}$ was found in Allied hospital. Calcium \& magnesium of T.B hospital $(544 \mathrm{mg} / \mathrm{l})$ and Iqbal hospital $(249 \mathrm{mg} / \mathrm{l})$ were highest respectively. The number of bicarbonates and chlorides in T.B hospital \& Faisal hospital was $1000 \mathrm{mg} / \mathrm{l}$ and $1568 \mathrm{mg} / \mathrm{l}$, beyond the recommended WHO values. Descriptive statistics was applied to data to evaluate the significant differences between the means of samples. Results demonstrate that sewage water of Allied hospital, Faisalabad hospital, Iqbal hospital and T.B hospital is not ecofriendly and highly unfit for aquatic and human life.

Keywords: Aquatic life; Blood; Contamination; Eco-friendly; Physicochemical parameters;

Sewage water; WHO

\section{Introduction}

Water is the most principal component of life. About $75 \%$ of our earth is enclosed by water, out of this only $1 \%$ is freshwater. Due to its polar nature, it dissolves many things in it. It is the most vital thing that has uninterrupted effects on the life of any living organism. Water defilement is one of the alarming problems in our society and in which nonstop dispose of sewage water without treatment. This sewage water also includes sewage water of hospitals and laboratories without any management. Blood and urine both are major agents that are present in the sewage of hospitals and should be cured prior to discharging in sewage outlets. For instance, the compounds which are used for its treatment are itself the cause of contamination [1] and this pollution may cause secondary pollution. 
Waste of hospitals contains many microorganisms comprising pathogenic species [2]. Other than many pathogens, hospitals sewage water also includes a great number of antibiotics [3]. The physicochemical parameters like total hardness $(\mathrm{TH})$, total dissolved solids (TDS), calcium, chlorides, carbonates and bicarbonates are also analyzed in it. The antibiotics which are not completely metabolized in animal and the human body are excreted through excreta and it is a major source of antibiotics in the ecosystem. Commercial areas like hospitals are major dissolved of antibiotics to municipal waste [4, 7]. The wastewater coming from hospitals and laboratories contains too much pathogens, fecal matters, blood, disinfectants, antibiotics and so much of the heavy metals dissolved in it.

The demand for water in hospitals is $500 \mathrm{~L}$ per bed per day which is far more than the consumption of residences which is $100 \mathrm{~L}$ per head per day [8]. The alarming issue is that this hospital wastewater is disposing of in the ecosystem same as the household sewage [9]. This sewage water is directly disposed of in freshwater bodies without any treatment [2]. The Taiwan Environmental Protection Agency (TEPA) has passed a law that hospitals should have sewage water treatment plants that treat the wastewater before it is discharged. If this water is disposed of without treatment, then this water not only affects badly to human beings but also to aquatic life. Wastewater treatment does not completely remove the antibacterial medicines from hospital effluents and that remainings ultimately disposed of in groundwater [10]. The wastewater coming from hospital outlets is greater than the sewage water of housing colonies.
Normally the methods used to treat the sewage water are activated sludge process (AS), contact aeration process (CA), rotating biological contractors (RBC), trickling filters (TF) and chemical coagulation $(\mathrm{CH})$. The number of micro-organisms removed depends on which type of treatment you are using. The number of microorganisms can be decreased by following microbiological guidelines. In a simple settling tank process about $50 \%$ to $60 \%$ viruses can be eliminated [11]. The research of United States Environmental Protection Agency (USEPA) has recently detected that relative contributions of pharmaceutically active compounds (PhACs) from residential effluents, hospital wastewater and concentrated animal feeding operation (CAFO) effluent required topmost research [12]. The topmost antibiotics like sulfonamide, fluoroquinolone and macrolide are identified in waste and surface water [13]. The present study was conducted to distinguish the chemical and physical nature of sewage water of hospitals and those parameters were compared with standard values given by water and sanitation agency of Pakistan and WHO guidelines.

\section{Materials and methods Sample collection}

The present study was intended from different hospitals of Faisalabad, Pakistan to estimate the physicochemical parameters of hospitals sewage water. Thirteen hospitals i.e. Allied hospital, Kardar hospital, United hospital, Chiniot hospital, Al-Noor hospital, Faisal hospital, Mian Trust hospital, T.B. hospital, Hilal-e-Ahmar hospital, DHQ hospital, Yaseen Memorial hospital, Social Security hospital and Iqbal hospital were selected for collection of samples. Samples were taken from boreholes of hospitals. 


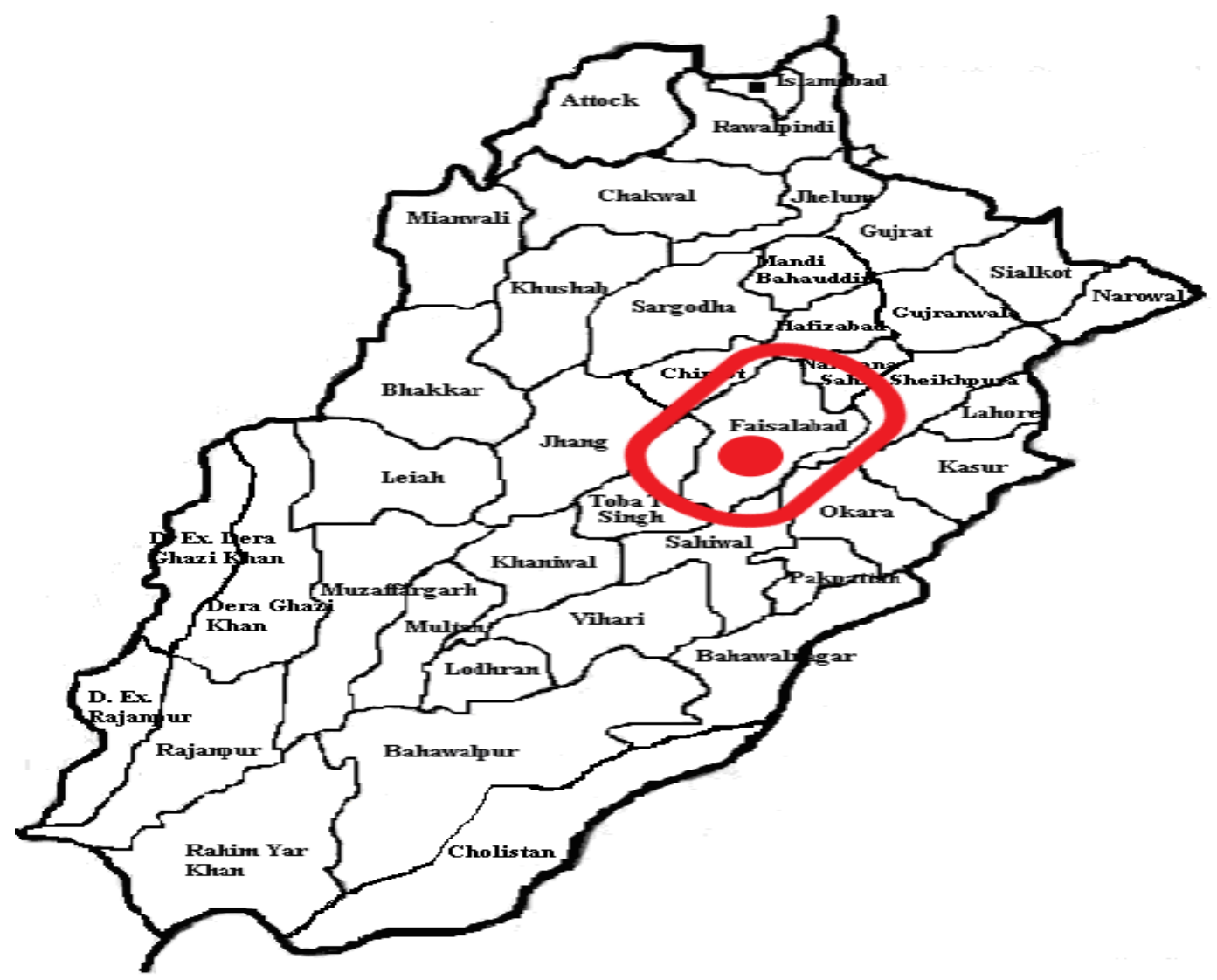

Figure 1. Location of the sampling area

\section{Preparation of samples}

The samples were placed in small sampling bottles which were washed with distilled water before placing the samples to ensure the maximum accuracy. After taking the samples, the bottles were labeled to avoid any mixing of bottles. The samples of each hospital covered the whole area of the hospital. Samples were kept at $4^{\circ} \mathrm{C}$ in the freezer.

\section{Analysis of water sample}

After sampling, the experimentation is performed in the Water and Sanitation Agency, Faisalabad. Five parameters i.e. Total hardness, Total dissolved solids, Calcium, Chloride, Magnesium and Bicarbonate experimented through the titration process.

\section{Determination of sewage water quality parameters}

The wastewater quality parameters were analyzed as follows: total dissolved solids (TDS) were estimated by a standard method, calcium contents and total hardness $(\mathrm{TH})$ by EDTA titrimetric method, chloride contents by argentometric method and bicarbonates by using methyl orange.

\section{Statistical analysis}

Statistical analysis was applied to complete the data set of hospital wastewater. Suitable tables were arranged, and means were assessed. Descriptive statistics was applied to check the difference at a certain level.

\section{Results and discussion}

This study was conducted to analyze the physicochemical parameters (TDS, Total hardness, calcium, magnesium, chlorides, bicarbonates) of sewage water from thirteen 
different hospitals of District Faisalabad, Pakistan. The focus of this analysis was to determine whether these sewage water parameters from hospitals were ecofriendly or not. Table 1 exhibited that the mean values of physicochemical parameters vary significantly. Mean TDS value was 1659.23 $\mathrm{mg} / \mathrm{l}$ followed by $466.46 \mathrm{mg} / \mathrm{l}$ (total hardness), $180.61 \mathrm{mg} / \mathrm{l}$ (calcium), $75.53 \mathrm{mg} / 1$ (magnesium), $538.30 \mathrm{mg} / \mathrm{l}$ (chlorides) and $669.07 \mathrm{mg} / \mathrm{l}$ (bicarbonates) respectively. Mean TDS, bicarbonates and chlorides values were not according to the WHO recommended guidelines, proving not ecofriendly. As [9] studies explained the contamination level and side effects of hospital sewage water in his study. His study relates to the above-mentioned study that is on the physicochemical analysis of sewage water and analysis of variance. Results showed that this sewage water is highly contaminated and should not be disposed of without treatment.
In the water sample of Allied hospital TDS, total hardness and chlorides were beyond the given values while calcium and magnesium were within range. The TDS value of all the hospitals was exceeding the normal value except Al-Noor and Hilal e Ahmar hospital. Total hardness assessed values of Allied, Kardar and United hospital were beyond the limit while the other hospitals' values were in range. The tested water samples of T.B, Iqbal, Faisal and United hospital revealed the high values of calcium whereas, other hospitals showed within range values. The water sample of Iqbal hospital and T.B hospital exhibited surpass values of magnesium while the United, Faisal, Hilal e Ahmar and DHQ revealed below the range values. Tested water sample of Al-Noor hospital showed below the range bicarbonate value whereas other hospitals revealed within range values. The water sample of all hospitals exhibited high chloride value except Al-Noor hospital (Table 2).

Table 1. Descriptive statistical analysis of all physicochemical parameters

\begin{tabular}{|c|c|c|c|c|c|c|}
\hline $\begin{array}{c}\text { Statistical } \\
\text { factors }\end{array}$ & TDS & $\begin{array}{c}\text { Total } \\
\text { Hardness }\end{array}$ & Calcium & Magnesium & Bicarbonates & Chlorides \\
\hline Mean & 1659.23 & 466.46 & 180.61 & 75.53 & 669.07 & 538.30 \\
\hline Median & 1500.00 & 480.00 & 112.00 & 55.00 & 616.00 & 374.00 \\
\hline Mode & N/A & 480.00 & N/A & 51.00 & N/A & N/A \\
\hline $\begin{array}{c}\text { Standard } \\
\text { Error }\end{array}$ & 167.51 & 21.24 & 46.30 & 20.75 & 44.35 & 108.21 \\
\hline $\begin{array}{c}\text { Standard } \\
\text { Deviation }\end{array}$ & 603.99 & 76.60 & 166.93 & 74.82 & 159.93 & 390.18 \\
\hline $\begin{array}{c}\text { Sample } \\
\text { Variance }\end{array}$ & 364807.7 & 5868.1 & 27868.8 & 5599.4 & 25579.1 & 152247.2 \\
\hline Kurtosis & -0.85 & -0.44 & 2.10 & 2.24 & 0.04 & 3.20 \\
\hline Skewness & 0.16 & -0.57 & 1.77 & -0.57 & 1.03 & 1.76 \\
\hline Range & 2010.00 & 244.00 & 491.00 & 248.00 & 528.00 & 1364.00 \\
\hline Minimum & 700.00 & 336.00 & 53.00 & 1.00 & 472.00 & 204.00 \\
\hline Maximum & 2710.00 & 580.00 & 544.00 & 249.00 & 1000.00 & 1568.00 \\
\hline Sum & 21570.00 & 6064.00 & 2348.00 & 982.00 & 8698.00 & 6998.00 \\
\hline $\begin{array}{c}\text { Confidence } \\
\text { Interval } \\
\text { (95.0\%) }\end{array}$ & 1294.24 & 420.17 & 79.73 & 30.32 & 572.42 & 302.51 \\
\hline
\end{tabular}


Table 2. Physicochemical parameters of different hospitals wastewater

\begin{tabular}{|c|c|c|c|c|c|c|c|}
\hline Sr. No. & Hospitals & TDS & $\begin{array}{c}\text { Total } \\
\text { Hardness }\end{array}$ & Calcium & Magnesium & Bicarbonates & Chlorides \\
\hline Units & & Mg/l & Mg/l & Mg/l & Mg/l & $\mathbf{M g} / \mathbf{l}$ & Mg/l \\
\hline $\begin{array}{c}\text { WHO } \\
\text { guideline }\end{array}$ & & $\begin{array}{c}1000 \\
\mathrm{mg} / \mathrm{L}\end{array}$ & $\begin{array}{c}10- \\
500 \mathrm{mg} / \mathrm{L}\end{array}$ & $\begin{array}{c}75- \\
200 \mathrm{mg} / \mathrm{L}\end{array}$ & $50-150 \mathrm{mg} / \mathrm{L}$ & $<500 \mathrm{mg} / \mathrm{L}$ & $250 \mathrm{mg} / \mathrm{L}$ \\
\hline 1 & $\begin{array}{c}\text { Allied } \\
\text { hospital }\end{array}$ & 2370 & 580 & 134 & 61 & 596 & 264 \\
\hline 2 & $\begin{array}{c}\text { Kardar } \\
\text { hospital }\end{array}$ & 1720 & 520 & 101 & 67 & 640 & 374 \\
\hline 3 & $\begin{array}{c}\text { United } \\
\text { hospital }\end{array}$ & 1110 & 512 & 206 & 1 & 756 & 248 \\
\hline 4 & $\begin{array}{l}\text { Chiniot } \\
\text { hospital }\end{array}$ & 2130 & 372 & 58 & 51 & 840 & 848 \\
\hline 5 & $\begin{array}{l}\text { Al-noor } \\
\text { hospital }\end{array}$ & 700 & 336 & 53 & 51 & 472 & 204 \\
\hline 6 & $\begin{array}{c}\text { Faisal } \\
\text { hospital }\end{array}$ & 2710 & 556 & 208 & 9 & 540 & 1568 \\
\hline 7 & $\begin{array}{c}\text { Mian trust } \\
\text { hospital }\end{array}$ & 1500 & 496 & 110 & 55 & 572 & 450 \\
\hline 8 & $\begin{array}{c}\text { T.B } \\
\text { hospital }\end{array}$ & 1270 & 480 & 544 & 220 & 1000 & 296 \\
\hline 9 & $\begin{array}{l}\text { Hilal-e- } \\
\text { ahmer }\end{array}$ & 920 & 468 & 154 & 21 & 542 & 260 \\
\hline 10 & DHQ & 1460 & 436 & 112 & 39 & 628 & 484 \\
\hline 11 & $\begin{array}{c}\text { Yaseen } \\
\text { memorial }\end{array}$ & 1420 & 488 & 72 & 77 & 616 & 356 \\
\hline 12 & $\begin{array}{c}\text { S.security } \\
\text { hospital }\end{array}$ & 2300 & 480 & 62 & 81 & 580 & 946 \\
\hline 13 & Iqbal & 1960 & 340 & 534 & 249 & 916 & 700 \\
\hline
\end{tabular}

Graph 1 showed the total dissolved solids and total hardness values of physicochemical parameters of different hospitals located in Faisalabad. $2710 \mathrm{mg} / \mathrm{l}$ was the maximum recorded TDS value of Faisal hospital which was very high from WHO recommended value $(1000 \mathrm{mg} / \mathrm{l})$ followed by $700 \mathrm{mg} / \mathrm{l}$ noted from Al-Noor hospital as compared to the other hospitals. Greater TDS from the recommended range exhibited that the water of Faisal hospital is seriously hazardous for both human and aquatic life. The total hardness value of Allied hospital was highest $(580 \mathrm{mg} / \mathrm{l})$ whereas, the lowest value (336 $\mathrm{mg} / \mathrm{l})$ was recorded from Al-Noor hospital. Both these values were in the normal range.
[14] explained the physicochemical and genotoxicity analysis. The physicochemical test showed that the direct dispose of sewage water increased the amount of total dissolved solids in it. The mixtures of chlorides, sulphates and bicarbonates increased the probability of toxicity in aquatic organisms. In the graphical representation (Graph 2) calcium value of T.B hospital was maximum $(544 \mathrm{mg} / \mathrm{l})$ in this assessment of wastewater whereas, Al-Noor hospital had low calcium $(53 \mathrm{mg} / \mathrm{l})$ in its water. Iqbal hospital magnesium value $(249 \mathrm{mg} / \mathrm{l})$ was beyond the WHO given value $(50-150 \mathrm{mg} / \mathrm{l})$ as compared to the other hospitals. The lowest magnesium $(1 \mathrm{mg} / \mathrm{l})$ value was recorded in 
the United hospital. Surpassing level of both calcium and magnesium revealed that water of these hospitals was seriously perilous. The study by [15] demonstrated the effects of sewage water on the saturation of calcium. Results elaborated that $120 \mathrm{mg} / \mathrm{l}$ value of $\mathrm{Ca}$ was recorded while the recommended value for calcium was $85-150 \mathrm{mg} / 1$. The high content of calcium makes the water alkaline and color changes to milky which making it unfit for human use but also infectious for aquatic life.

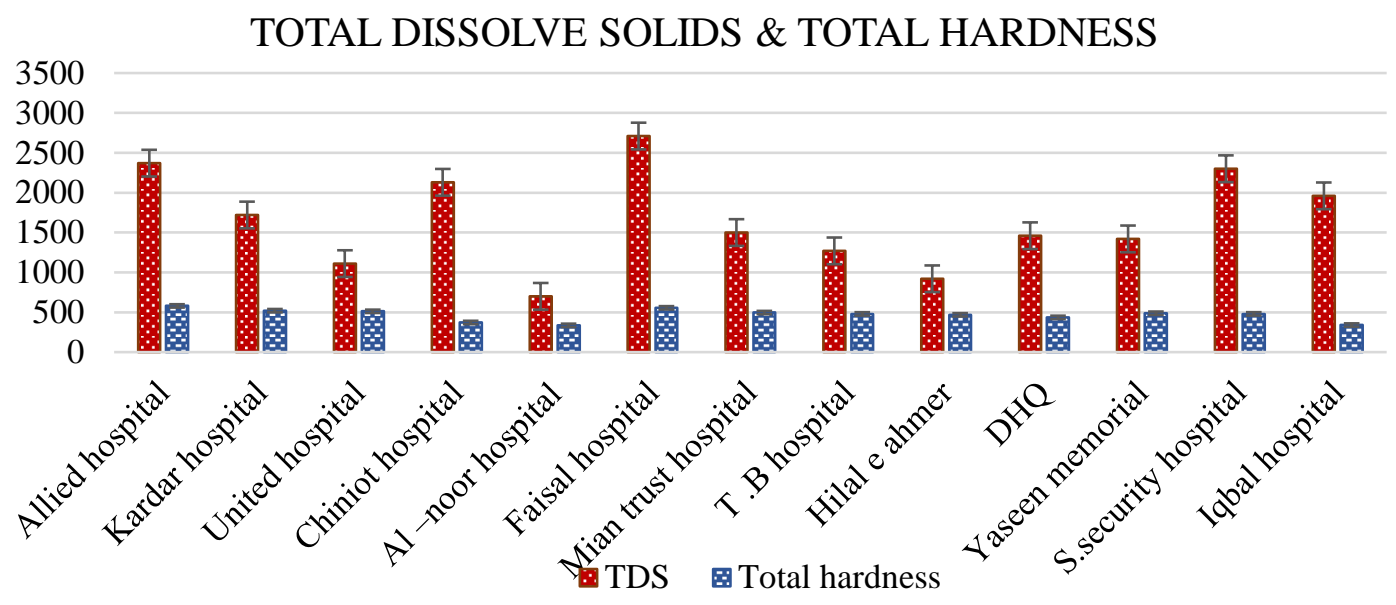

\section{Graph 1. Comparison of total dissolved solids and total hardness in the wastewater of different hospitals in Faisalabad}

\section{Calcium \& Magnesium}

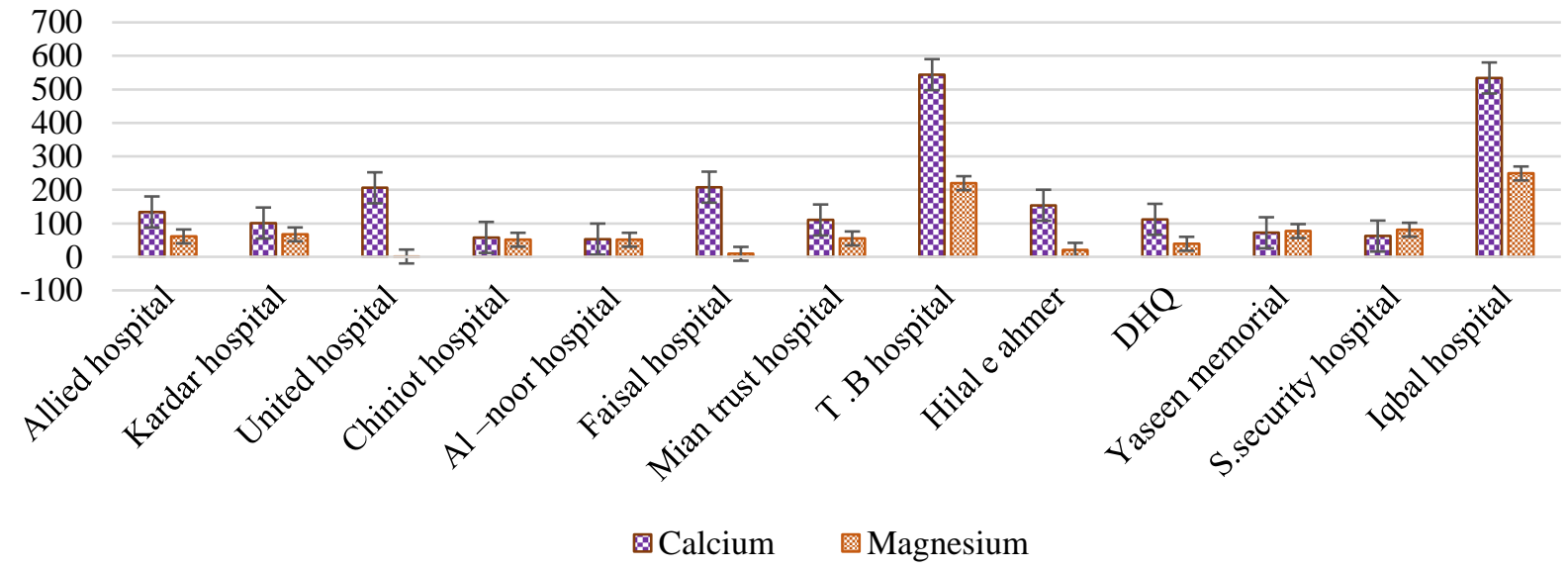

Graph 2. Comparison of calcium and magnesium in waste water of different hospitals in Faisalabad

Graph 3 exhibited the bicarbonates and chlorides existing in the water of different hospitals. $1000 \mathrm{mg} / \mathrm{l}$ was the maximum noted bicarbonate value of T.B hospital. The lowest bicarbonates value $472 \mathrm{mg} / \mathrm{l}$ was documented in Al-Noor hospital. The chloride value (1568 mg/l) of Faisal hospital water was high while the Al-Noor hospital possesses the 
lowest chloride value (204 mg/l). Exceeding levels of both bicarbonates and chlorides showed that the water of these hospitals is lethal for aquatic and human life. The study of [16] illustrated that the concentration of organochlorides was $0.09 \mathrm{mgAOX} / \mathrm{L}$ in hospital water which was not a suitable amount for the survival of aquatic life and human.

\section{Chlorides \& Bicarbonates}

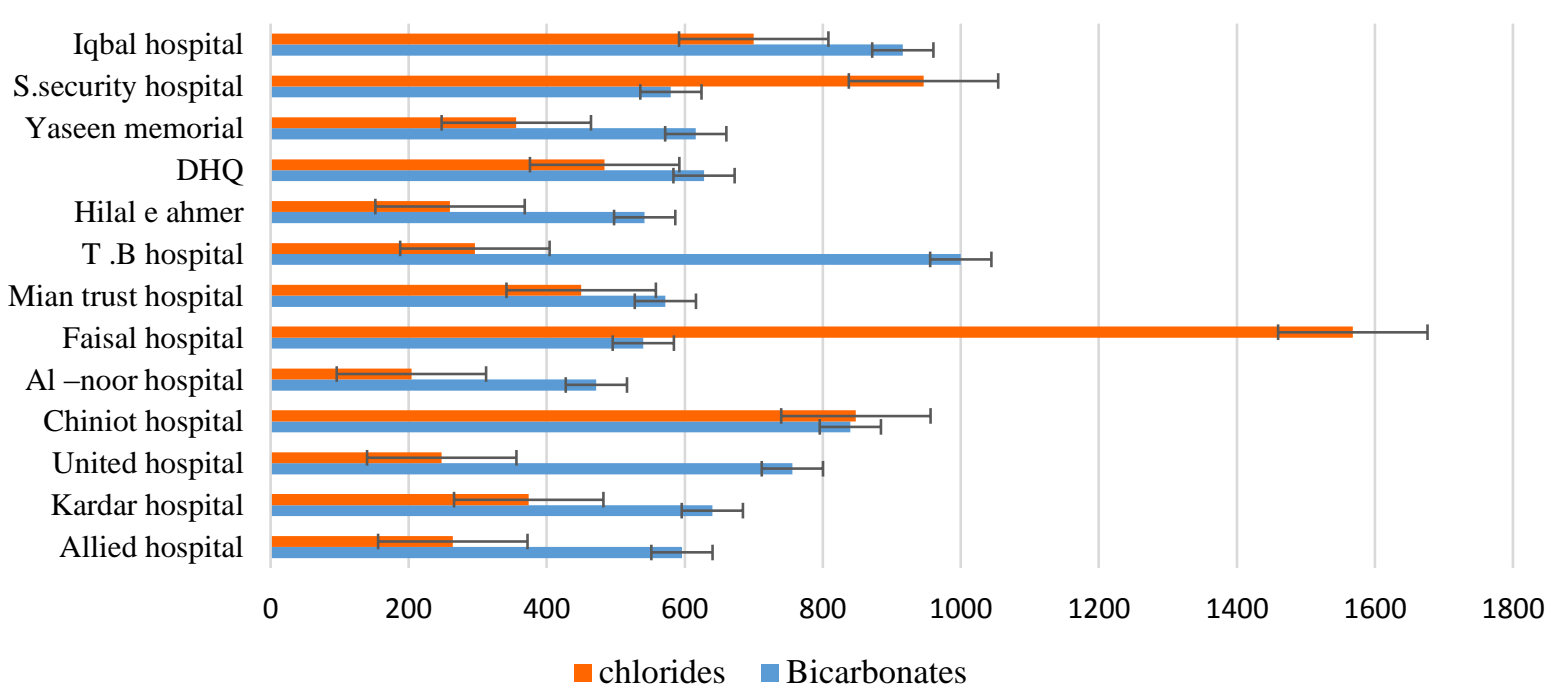

Graph 3. Comparison of chlorides and bicarbonates in the wastewater of different hospitals in Faisalabad

\section{Conclusion}

The evaluation of wastewater parameters from thirteen hospitals of Faisalabad city proved that all the tested physicochemical parameters (TDS, total hardness, calcium, magnesium, bicarbonates, chlorides) are surpassing the WHO recommended values. All the hospitals do not treat their sewage water well except Al-Noor hospital and when this wastewater mix with freshwater it becomes unfit for both aquatic and human lives. From the results, it is concluded that the wastewater of Faisalabad hospitals is seriously hazardous as it contains all physicochemical parameters that surpass the WHO guidelines. It is suggested that there should be proper channels to dispose of the wastewater to keep aquatic environments clean and less hazardous.

\section{Authors' contributions}

Conceived and designed the experiments: $\mathrm{H}$ Rehman \& NA Khan, Performed the experiments: $\mathrm{H}$ Hira, Analyzed the data: $\mathrm{H}$ Rehman, Contributed materials/ analysis/ tools: A Bibi \& H Hira, Wrote the paper: H Rehman \& NA Khan

\section{Acknowledgment}

All the authors have a contribution to work.

\section{References}

1. Pruss A, Girouit E \& Rushbrook P (1999). Safe management of waste from health care activities. WHO 2: 2-3.

2. Tsai CT, Lai JS \& Lin ST (1998). Quantification of pathogenic microorganisms in the sludge from treated hospital wastewater. J App Micro Bio 85: 171-176.

3. Levy SB \& Marshall B (2004). Antibacterial resistance worldwide: 
causes, challenges and responses. Nat Med 10: 122-129.

4. Guardabassi L, Petersen A, Olsen JE \& Dalsgaard A (1998). Antibiotic Resistance in Acinetobacter spp. Isolated from Sewers Receiving Waste Effluent from a Hospital and a Pharmaceutical Plant. Appl Environ Microbiol 64(9): 3499-3502.

5. Hartmann A, Golet EM, Gartiser S, Alder AC, Koller $\mathrm{T}$ \& Widmer RM (1999). Primary DNA damage but not mutagenicity correlates with ciprofloxacin concentrations in German hospital wastewaters. Arch Environ Contam Toxicol 36(2): 115-9.

6. Alder J, Thakker-Varia S, Bangasser DA, Kuroiwa M, Plummer MR, Shors TJ \& Black IB (2003). Brain-derived neurotrophic factor-induced gene expression reveals novel actions of VGF in hippocampal synaptic plasticity. $J$ Neurosci. 26;23(34):10800-8.

7. Giuliani M, Herman JD, Castelletti A \& Reed P (2014). Many-objective reservoir policy identification and refinement to reduce policy inertia and myopia in water management. Water Resour Res 50(4): 3355-3377.

8. Gadelle F (1995). Le monde manquerat-il bientôt d'eau? Sécheresse 1: 11-15.

9. Emmanuel E, Pierre MG \& Perrodin Y (2009). Groundwater contamination by microbiological and chemical substances released from hospital wastewater: Health risk assessment for drinking water consumers. Envr Int 35: 718-726.

10. Daughton CG \& Ternes TA (1999). Pharmaceuticals and personal care products in the environment: agents of subtle change? Environ Health Perspect 6: 907-938.

11. Rao VC, Lakhe SB \& Raman SV (1981). Virus removal in primary settling of raw sewage. J Environ Engr Div 107: 57-66.

12. Daughton CG (2004). Non-regulated water contaminants: emerging research. Environ Impact Asses Rev 24(8): 711732.

13. Huang JN, Park I, Ellingson E, Littlepage LE \& Pellman D (2001). Activity of the APC $(\mathrm{Cdh} 1)$ form of the anaphase-promoting complex persists until $\mathrm{S}$ phase and prevents the premature expression of Cdc20p. J Cell Biol 154(1): 85-94.

14. Hailu T, Chalie A \& Yilma D (2018). Analysis of the level of some selected physicochemical parameters present in wastewater effluent discharged from Wolkite University, Gurage Zone, Ethiopia. J Anal Bioanal Tech 9(5): 413.

15. Neal C, Jarvie HP, Williams RJ, Neal M, Wickham H \& Hill L (2002). Phosphorus-calcium carbonate saturation relationships in a lowland chalk river impacted by sewage inputs and phosphorus remediation: an assessment of phosphorus self-cleansing mechanisms in natural waters. Sci Total Environ 283: 295-310.

16. Emanuel EJ, Wendler D, Killen J \& Grady C (2004). What makes clinical research in developing countries ethical? The benchmarks of ethical research. $J$ Infect Dis 189(5): 930-7. 